\title{
Research on SWOT Analysis for Technical Innovation Strategy of a Yunnan-stationed Mining Enterprise
}

\author{
Bingjing Yin \\ $S \&$ T Office \\ Kunming Metallurgy College \\ Kunming, Yunnan, China 650033 \\ Jinfeng Huang \\ $S \& T$ Office \\ Kunming Metallurgy College \\ Kunming, Yunnan, China 650033 \\ Xiaoju Zhou \\ PE Office \\ Kunming Metallurgy College \\ Kunming, Yunnan, China 650033
}

\author{
Shiting Ding \\ $S$ \& T Office \\ Kunming Metallurgy College \\ Kunming, Yunnan, China 650033 \\ Ying Wang \\ $S$ \& T Office \\ Kunming Metallurgy College \\ Kunming, Yunnan, China 650033

\section{Guimei Xiang} \\ President Office \\ Kunming Metallurgy College \\ Kunming, Yunnan, China 650033
}

\begin{abstract}
Technical innovation plays an important role in the future development of an enterprise, which has in recent years become a hot point in the management science field. Starting with technical innovation, this article takes a Yunnanstationed mining enterprise to research and analyze how to drive the development of the enterprise in the long run through proving core competitiveness on the basis of technical innovation. The SWOT analysis is conducted upon the technical innovation, status quo and existing problems so as to determine the selection of technical innovation strategy mode and measures to perfect the technical innovation strategy and to further provide theoretical support and experience reference and for the overall strategy decision-making of the enterprise.
\end{abstract}

Keywords-a mining enterprise in Yunnan; SWOT analysis; innovative technology strategy

\section{INTRODUCTION}

Technical innovation, a hot point for research in management science, was first seen in a 1912 Theory of Economic Development, written by Joseph Alois Schumpeter, an Austrian American economist, which attracted all eyeballs of universities and research institutes around the world[1]. In the 1970s, N. Abernathy and Jame.M.Utterback, America scholars, put forward an AU model [2] on the basis of life cycle theory, in the 1990s, Douglass C. North, a Nobel award winner, introduced the path dependence theory into the study on institutional changes, all were innovation and inheritance of

Fund Project: Scientific Research Project of Yunnan Educational Department: Research on Development of Mineral Resources-based Enterprises in Yunnan Driven by Technical Innovation (2012G176).

CLC number: Document code: A Article ID:

Fund Project: project title and number. Such as the 2014 Yunnan Higher Vocational Education Scientific Research Project: Mine Safety Simulation Evaluation System Development (GZYB201404). the theory of technical innovation. As one of the founders of the technical economy and innovation management, Professor $\mathrm{Fu}$ Jiaji wrote Technological Innovation in 1998, which was a works showing technical innovation through systematic discussion on the basis of the situation in China, and an attempt for creating the Technical Innovation [3].

The Yunnan-stationed mining enterprise, the first reorganized by industrial administration authority in the province, is an enterprise group which is mainly engaged in collection, process and scientific research of five largest minerals such as aluminum, lead zinc, manganese, titanium and silicon. Its annual yield reaches 10 millions, mineral processing 11 million tons, smelting 2.2 million tons and deep processing 0.6 million tons. The enterprise has won honors and certificates as China Top 10 Transformation and Upgrade Model Enterprises, China Most Influential Enterprises, China Good Faith Demonstration Enterprises and so on. However, on a new starting point in the history, it is a must for us to know how to ensure the large group to exert its leading role in promoting the nonferrous metals industry in China and pushing the industrial transformation and upgrade in Yunnan province, accordingly this article suggests that a SWOT analysis should be conducted on the problems arising out of the operation of the enterprise so as to find a way for leap development through technical innovation. 


\section{TECHNICAL INNOVATION AND SWOT}

\section{A. Technical Innovation}

According to the definition of technical innovation that $\mathrm{Fu}$ Jiaji, a professor of Tsinghua University, gave in his works Technical Innovation, the technical innovation is a game process between enterprises and markets, after technical innovation, enterprises need to reorganize production conditions and factors to establish a production and operation system more suitable for the market economy so as to earn more business benefits[3].

Metallurgical industry is one of the backbone industries in China. However, facing current situation and under the impact of new industries such as computers and electronic information, the metallurgical industry is faced with a series of problems as lack of talents, economic restructuring, excess capacity and so on, and how to keep a healthy and steady development in the fierce market competition has been a major problem to be solved for most enterprise groups[5,6]. In order to get rid of the predicament, the enterprises have to depend on technical innovation and reorganize the production conditions and factors in new raw materials, new processes and new products; create new business models in new markets, new marketing and new customers; coordinate functions of internal departments in new cultivation, new management and new organization. And make the enterprise have a new look from inside to outside under the guidance of technical innovation.

\section{B. SWOT Analysis}

SWOT analysis is a scientific method through which an enterprise may conduct an overall analysis on itself to determine the strength, weakness, opportunities and threats that it owns or face during the competition so as to co-ordinate internal resources and external environment. With the SWOT analysis used flexibly, it can make a comprehensive, systematic and accurate analysis upon the object concerned within a certain period of time so as to determine scientific strategies for the development of the enterprise in next periods. Yet, the scientificity and reliability of the SWOT analysis depend largely on the professional skills and knowledge reserves of participants in the analysis process, which is a qualitative method unable to quantify the process, what it gives more for decision makers is empirical reasoning, unable to meet the requirements of quantitative analysis. In order to make up the defects of the SWOT analysis and make it more widely applied in deeper levels, many scholars have made the exploratory researches and improvement on it. When analyzing the background of an enterprise, a PEST analysis method is generally added, P: Politics, E: Economy, S: Society, T: Technology [8], which are used to analyze the situation that the enterprise group is in. In the meantime, some suggest that the APH (Analytic Hierarchy Process) should be adopted to classify complicated problems and make the analysis process much rational and judge as per the objective reality, through two-two comparison, experts' opinions and analysts' impersonal judgment are well combined to make comparison between each two elements of analytic hierarchy and achieve the purpose of quantitative description. [9]
TABLE I. STRENGTH IN TECHNICAL INNOVATION STRATEgY

\begin{tabular}{|c|c|c|}
\hline Type & & Factors \\
\hline $\begin{array}{l}\text { Strength } \\
\text { in } \\
\text { structure }\end{array}$ & $\begin{array}{l}\text { Operation } \\
\text { scale }\end{array}$ & $\begin{array}{l}\text { The financial statistics as of the first half of } 2015 \\
\text { showed, the Yunnan-stationed mining company } \\
\text { had assets of } 33.1 \text { billion yuan in the total, the } \\
\text { operating income reached } 10.518 \text { billion yuan, } \\
\text { and it was is one of the ten key industrial } \\
\text { enterprise supported by Yunnan Provincial } \\
\text { People's Government, ranking } 267 \text { in China top } \\
500 \text { enterprises, which is directly under the } \\
\text { supervision of State-owned Assets Supervision } \\
\text { and Administration Commission of Yunnan } \\
\text { Provincial People's Government. }\end{array}$ \\
\hline \multirow{3}{*}{$\begin{array}{l}\text { Strength } \\
\text { in } \\
\text { technical } \\
\text { innovatio } \\
\text { n }\end{array}$} & Full drive & $\begin{array}{l}\text { It has formed an annual yield of mining of } 1.08 \\
\text { million tons, dressing of } 1.07 \text { million tons, } \\
\text { smelting of } 710,000 \text { tons, deep processing of } \\
190,000 \text { tons, germanium products of } 20 \text { tons, } \\
\text { manganese ore of } 380,000 \text { tons, ferroalloy of } \\
200,000 \text { tons and sulfuric acid of } 37 \text { million } \\
\text { tons. The group owns a national technical center, } \\
\text { a national class A large-scale integrated design } \\
\text { and research institute, as well as a post-doctoral } \\
\text { research station, two of which are listed } \\
\text { companies in Share A. }\end{array}$ \\
\hline & $\begin{array}{l}\text { High } \\
\text { efficiency }\end{array}$ & $\begin{array}{l}\text { The company highly values the upgrading of } \\
\text { brand images, adhere to the coordinated } \\
\text { development with the various stakeholders. It } \\
\text { has a trademark well-known at home, and the } \\
\text { products as lead ingots, zinc ingots are registered } \\
\text { for transaction at LME and the Shanghai Metal } \\
\text { Exchange, the silver ingots are registered at } \\
\text { LBMA. Owning five trademarks famous at } \\
\text { home and ten famous trademarks in Yunnan } \\
\text { Province; won the title of national advanced } \\
\text { mining enterprise in rational development and } \\
\text { utilization of mineral resources, } 46 \text { scientific and } \\
\text { technological achievements at provincial or } \\
\text { ministry level, } 64 \text { patents approved. }\end{array}$ \\
\hline & $\begin{array}{l}\text { New } \\
\text { technology }\end{array}$ & $\begin{array}{l}\text { Starting from the Eleventh Five-Year Plan, its } \\
\text { cumulative investment has reached nearly } 40 \\
\text { billion yuan for about } 50 \text { projects in energy- } \\
\text { saving, emission reduction and recycling } \\
\text { economy, making efforts to promote the low- } \\
\text { carbon development to green ecological } \\
\text { development. Especially in recent three years, } \\
\text { with the metal production growing more than } \\
22 \% \text {, it has saved the energy of } 122000 \text { tons of } \\
\text { standard coal and reduced the emission of sulfur } \\
\text { dioxide of nearly } 3,000 \text { tons, exceeding the } \\
\text { government's goals in energy saving, various } \\
\text { indices of environmental protection are leading } \\
\text { in the same trade at home; Select Huize and } \\
\text { Yiliang mines for green development, and the } \\
\text { technology of lead and zinc smelting is a } \\
\text { benchmark for the lead and zinc smelting at } \\
\text { home. }\end{array}$ \\
\hline \multirow[t]{2}{*}{$\begin{array}{l}\text { Strength } \\
\text { in cost }\end{array}$} & $\begin{array}{l}\text { Centralized } \\
\text { capital } \\
\text { operation }\end{array}$ & $\begin{array}{l}\text { In } 2009 \text {, the Group's project was for the first } \\
\text { time approved by a finance company, which } \\
\text { means that it can realize the centralized } \\
\text { management in the fund operation and provide a } \\
\text { strong guarantee for the turnover of the } \\
\text { enterprise's capital flow. In the reform of capital } \\
\text { market, through the innovation, the stock of two } \\
\text { listed companies are split, make full use of the } \\
\text { market to bring benefits to the Group and also } \\
\text { establish a good image. }\end{array}$ \\
\hline & $\begin{array}{l}\text { Expansion } \\
\text { in a low } \\
\text { cost }\end{array}$ & $\begin{array}{l}\text { Owning lead and zinc mineral resources, the } \\
\text { company keeps a high rate of self supply of raw } \\
\text { materials, and the mines are in a high quality, so } \\
\text { the production cost is lower. }\end{array}$ \\
\hline
\end{tabular}




\section{ANALYSIS OF SWOT MODELING}

The SWOT analysis aims to provide a method of analyzing the influencing factors for the object concerned and the external conditions [10]. The analysis focuses on the internal and external factors of the object, analyzing the impact of each factor on a certain strategy of the enterprise, through the analysis of the status quo, it will be easy to know the strength and threats that the enterprise owns or face in the current development. According to the analysis results, establish a rational reasonable strategy for the next development and really achieve the development of enterprises like "specific solution for problems", enable the strength of enterprises to become the core competitiveness, and find a solution for troubles in the development.

\section{A. SWOT Modeling}

Make a qualitative description of elements involved in the SWOT

(1) Strength: The strength can be taken as positive and high-influential factors related to analysis of the enterprise. Generally it refers to the internal environment, to sum up the strength of an enterprise consists of strength in structure, strength in innovation and strength in cost, etc.

(2) Weakness: an internal factor for enterprise, mainly including outdated equipment, management out of order; lack of key technologies; poor in R\&D ; shortage of funds; improper operation; excessive inventory' poor in competitiveness. The above are summarized as three weakness:
TABLE II. WEAKNESS IN TECHNICAL INNOVATION STRATEGY

\begin{tabular}{ll}
\hline Type & \multicolumn{1}{c}{ Factors } \\
\hline & The operation and development of an enterprise both \\
are based on a certain capital reserves and capital \\
flows, and a great number of capitals will be needed \\
for resource exploitation, technical research and \\
development, enterprise construction and so on which \\
are closely related to the normal operation. Difficulty \\
in financing and lack of funds are challenges to face \\
frequently. The data statistics as of September 2015 \\
showed, the company's liabilities reached 21.9 billion \\
yuan, debt ratio of $66.27 \%$. \\
The sustainable development and the ecological \\
civilization construction under New Normal of \\
economy need a background of environment-friendly \\
and resource-saving for development, and the "three \\
wastes" shall be recycled as resources; the total sulfur \\
utilization rate shall reach 97\% or more; the \\
production wastewater shall be in a zero emission; the \\
harmless treatment rate of solid wastes shall reach \\
100\% and so on, making the technical research and \\
development in the face with new difficulties in \\
innovation. \\
Branches of the Group as subsidiaries, holding \\
companies, sole proprietorship companies, institutions \\
and so on shall take into account the overall operation \\
and development as well as characteristics of their \\
own; well do the division and cooperation between \\
"whole" and "partial". Improve the enterprise's entry \\
and exit mechanism, transform it to the capitalized \\
operation, accelerate the transformation of economic \\
growth mode, and deepen the structural reforms. \\
Management
\end{tabular}

(3) Opportunities: an external factor for enterprise, including new products; new markets; new demands; lifting of barriers to foreign markets; failure of competitors, PEST analysis is introduced here. As shown in "Fig. 1" below.

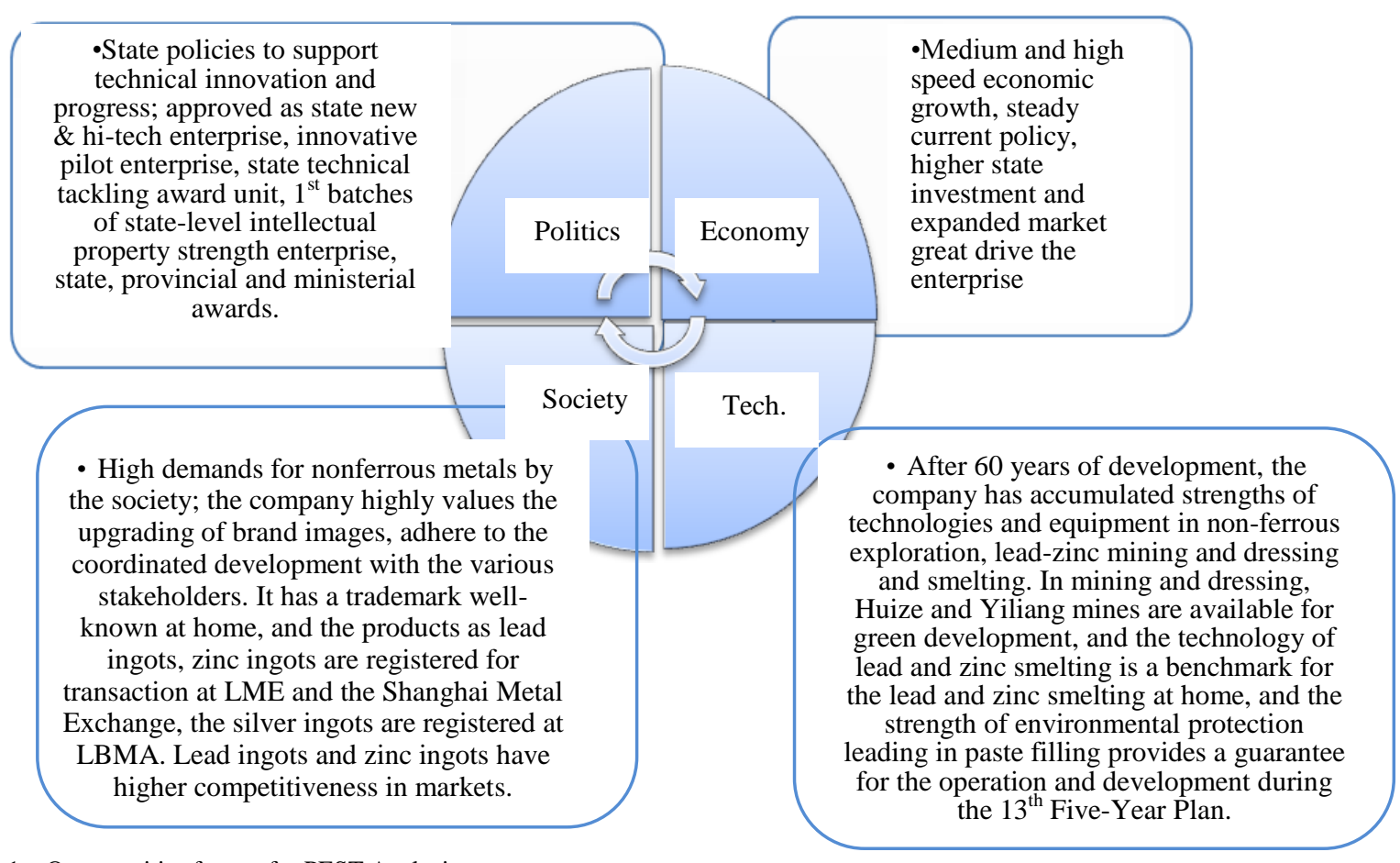

Fig. 1. Opportunities factors for PEST Analysis 
Threats: an external factor for enterprise, mainly including new competitors; an increase in alternative products; market tightening; industrial policy changes; economic recession; customers' preferences change; sudden events, etc.

\begin{tabular}{c}
$\begin{array}{c}\text { Politics: state policies to } \\
\text { encourage the development of } \\
\text { small and medium } \\
\text { enterprises; strengthen the } \\
\text { large state-owned enterprises } \\
\text { to compete for survival, } \\
\text { promote corporate }\end{array}$ \\
$\begin{array}{c}\text { Economy: In the first half } \\
\text { of 2015, the macro- } \\
\text { economic growth was in } \\
\text { forcing enterprises to adjust } \\
\text { the enterprise structure; } \\
\begin{array}{c}\text { Society: enterprises take } \\
\text { metal industry in } \\
\text { downturn and product } \\
\text { social responsibilities; } \\
\text { price swinging in a low } \\
\text { metallurgical costs and } \\
\text { resource costs change } \\
\text { with the development of } \\
\text { society. }\end{array} \\
\begin{array}{c}\text { Technology: Difficulties in } \\
\text { upgrading and }\end{array} \\
\text { reconstruction of existing } \\
\text { production process and } \\
\text { equipment via advanced and } \\
\text { new technologies, } \\
\text { elimination of those with } \\
\text { poor benefits for clean and } \\
\text { safe production, improve } \\
\text { production automation and } \\
\text { digital management. }\end{array}$ \\
\hline
\end{tabular}

Fig. 2. Threats in the PEST analysis

According to factors analysis, build a SWOT analysis model

TABLE III. SWOT MODEL

\begin{tabular}{|c|c|c|}
\hline Internal abilities & Strength & Weaknesses \\
\hline External factors & $\begin{array}{llll}S 1 & S 2 & S 3 & \ldots\end{array}$ & $W 1 W 2 W 3 \ldots$ \\
\hline Opportunities & SO & Wo \\
\hline $\mathrm{O} 1 \quad \mathrm{O} 2 \quad \mathrm{O} 3 \ldots$ & $\begin{array}{l}\text { Maximize the } \\
\text { strength in } \\
\text { development, } \\
\text { increase } \\
\text { opportunities }\end{array}$ & $\begin{array}{l}\text { Make use of } \\
\text { opportunities and avoid } \\
\text { from weakness }\end{array}$ \\
\hline Threats & ST & WT \\
\hline $\mathrm{T} 1 \quad \mathrm{~T} 2 \quad \mathrm{~T} 3 \ldots$ & $\begin{array}{l}\text { Make use of } \\
\text { strength, reduce } \\
\text { threats }\end{array}$ & Merge, shrink \\
\hline
\end{tabular}

\section{B. SWOT Analysis}

The basic core content of SWOT analysis is to complete the self-recognition and external environment cognition, after completion of the two procedures, it needs to build a SWOT analysis model which will further quantify the factors $(\mathrm{S}, \mathrm{W}, \mathrm{O}$, $\mathrm{T}$ ) and determine the influencing factors in the technical innovation strategy of the Yunnan-stationed mining enterprise [6].

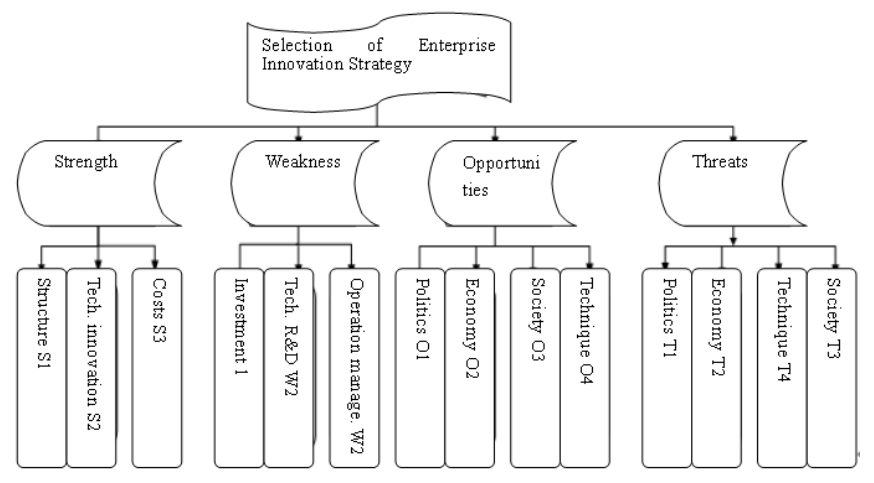

Fig. 3. AHP Diagram

According to the AHP diagram in Figure 3, create a the judgment matrix and make a pair-wise comparison and analyze the SWOT factors of the Yunnan-stationed mining enterprise[11]. According to the experts' evaluation, judge and determine the weight importance indices, relevant assignments shall be based on the classic assignment method in the SWOT analysis, as shown in Table 3.4 below.

TABLE IV. FUNDAMENTAL SCALES FOR PAIR-WISE COMPARISONS

\begin{tabular}{|c|c|c|}
\hline $\begin{array}{l}\text { Intensity of } \\
\text { Importance }\end{array}$ & ${ }^{w_{i}} \mathbf{S}$ & ${ }^{w_{j}}$ Scale \\
\hline $\begin{array}{l}w_{i} \quad \text { vs } w_{j}: \text { equal } \\
\text { importance }\end{array}$ & $a_{i j}=1$ & $a_{j i}=1$ \\
\hline $\begin{array}{l}w_{i} \text { vs } w_{j}: \text { moderate } \\
\text { importance }\end{array}$ & $a_{i j}=3$ & $a_{j i}=1 / 3$ \\
\hline $\begin{array}{l}w_{i} \quad \text { vs } \quad w_{j}: \text { strong } \\
\text { importance }\end{array}$ & $a_{i j}=5$ & $a_{j i}=1 / 5$ \\
\hline $\begin{array}{l}w_{i} \text { vs } w_{j} \text { :very strong } \\
\text { importance }\end{array}$ & $a_{i j}=7$ & $a_{j i}=1 / 7$ \\
\hline $\begin{array}{l}w_{i} \text { vs } w_{j}: \text { extreme } \\
\text { importance }\end{array}$ & $a_{i j}=9$ & $a_{j i}=1 / 9$ \\
\hline $\begin{array}{l}\text { Median value between } \\
\text { the above }\end{array}$ & $a_{i j}=2,4,6,8$ & $\begin{array}{l}a_{j i}=1 / 2,1 / 4,1 / 6, \\
1 / 8\end{array}$ \\
\hline Reciprocal & \multicolumn{2}{|c|}{$\begin{array}{l}\text { If the importance ratio between elements } i \text { and } j \\
\text { is } a_{i j} \text {, the importance ratio between elements } \\
j_{\text {and } i \text { is } a_{j i}=1 / a_{i j}}\end{array}$} \\
\hline
\end{tabular}

According to the scoring criteria given in Table 3.4, build a pair-wise comparison matrix, nine directors from functional departments of the Yunnan-stationed mining enterprise form an expert team to score the SWOT factors.

TABLE V. SWOT FOUR FACTORS PAIR-WISE COMPARISON MATRIX A

\begin{tabular}{lllll}
\hline \multicolumn{1}{c}{ A } & Strength & Weakness & Opportunities & Threat \\
\hline Strength & 1 & 4 & 5 & 7 \\
Weakness & $1 / 4$ & 1 & 2 & 5 \\
Opportunities & $1 / 5$ & $1 / 2$ & 1 & 3 \\
Threat & $1 / 7$ & $1 / 5$ & $1 / 3$ & 1 \\
\hline
\end{tabular}


TABLE VI. STRENGTH COMPARISON MATRIX S

\begin{tabular}{|c|c|c|c|}
\hline $\mathbf{S}$ & S1 & S2 & S3 \\
\hline S1 & 1 & 5 & 7 \\
\hline $\mathrm{S} 2$ & $1 / 5$ & 1 & 3 \\
\hline S3 & $1 / 7$ & $1 / 3$ & 1 \\
\hline
\end{tabular}

TABLE VII. WEAKNESS COMPARISON MATRIX W

\begin{tabular}{|c|c|c|c|}
\hline W & W1 & W2 & W3 \\
\hline W1 & 1 & 4 & 7 \\
\hline W2 & $1 / 4$ & 1 & 2 \\
\hline W3 & $1 / 7$ & $1 / 3$ & 1 \\
\hline
\end{tabular}

TABLE VIII. OPPORTUNITIES COMPARISON MATRIX O

\begin{tabular}{|c|c|c|c|c|}
\hline O & O1 & O2 & $\mathbf{O 3}$ & O4 \\
\hline O1 & 1 & 3 & 6 & 7 \\
\hline $\mathrm{O} 2$ & $1 / 3$ & 1 & 4 & 5 \\
\hline O3 & $1 / 6$ & $1 / 4$ & 1 & 3 \\
\hline $\mathrm{O} 4$ & $1 / 7$ & $1 / 5$ & $1 / 3$ & 1 \\
\hline
\end{tabular}

TABLE IX. THREAT COMPARISON MATRIX T

\begin{tabular}{|c|c|c|c|c|}
\hline $\mathbf{T}$ & T1 & $\mathrm{T} 2$ & T3 & T4 \\
\hline $\mathrm{T} 1$ & 1 & 3 & 7 & 8 \\
\hline $\mathrm{T} 2$ & $1 / 3$ & 1 & 3 & 5 \\
\hline T3 & $1 / 7$ & $1 / 3$ & 1 & 3 \\
\hline $\mathrm{T} 4$ & $1 / 8$ & $1 / 5$ & $1 / 3$ & 1 \\
\hline
\end{tabular}

According to the data given as above, calculate the eigenvalues and eigenvectors of the pair-wise matrix respectively; check the consistency according to CI, RI and CR [12]. And then calculate the overall hierarchical arrangement. As shown in Table 3.10 .

TABLE X. RESUlts OF OVERALl HiERARCHICAL ARRANGEMENT

\begin{tabular}{lcrrr}
\hline \multicolumn{1}{c}{ Factor } & $\mathbf{S}$ & $\mathbf{W}$ & $\mathbf{O}$ & $\mathbf{T}$ \\
\hline SWOT1 & 0.4395 & 0.1535 & 0.0718 & 0.0327 \\
SWOT2 & 0.1136 & 0.0459 & 0.0348 & 0.0134 \\
SWOT3 & 0.0485 & 0.0183 & 0.0129 & 0.0056 \\
SWOT4 & & 0.0067 & 0.0028 \\
\hline \multicolumn{4}{c}{$C R=\frac{\sum a_{n} \bullet C I_{n}}{a_{n} \bullet R I_{n}}$} \\
\multicolumn{5}{c}{ Based on the formula: }
\end{tabular}

Calculate the consistency ratio of the overall hierarchical arrangement, $\mathrm{CR}=0.0484<0.10$, passing the consistency check, showing that the overall hierarchical arrangement reflects the importance of factors to selection of strategies.

\section{SELECTION OF TECHNICAL INNOVATION STRATEGY AND MEASURES}

Both the qualitative and quantitative SWOT analysis are to make preparation for the follow-up selection of strategies. Next, according to the procedures for strategic formation, it needs to model a strategic quadrilateral in order to select the technical innovation strategy [13]. In order to model a quadrilateral, first create coordinate axes, take $(\mathrm{S}, \mathrm{W})$ as horizontal ordinate and $(\mathrm{O}, \mathrm{T})$ as vertical coordinate. Next, mark the weight values of factors in the analytical hierarchy process, refer to Table 3.10 for results. The value selection shall be based on the factors with the max influencing weight in the AHP. Finally according to the point coordinates from each quadrant, connect one by one to get a strategic quadrilateral, $S_{1} O_{1} W_{1} T_{1}$ as shown in "Fig. 4".

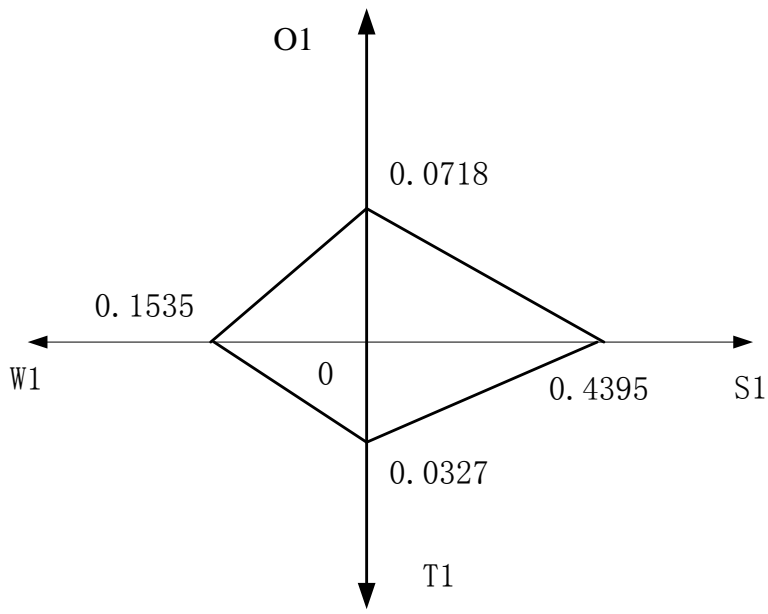

Fig. 4. Strategic quadrilateral S,O,W,T

Calculate the triangle area, then compare them and get:

$$
\begin{aligned}
& \mathrm{S} \Delta \mathrm{OS} 1 \mathrm{O} 1=1 / 2 \text { - } 0.43950 .0718=0.0158 \\
& \mathrm{~S} \Delta 0 \mathrm{~W} 1 \mathrm{O} 1=1 / 2 \text {. } 0.1535 \text { ? } 0.0718=0.0055 \\
& \mathrm{~S} \Delta 0 \mathrm{~S} 1 \mathrm{~T} 1=1 / 2 \text { 0.4395 } 0.0327=0.0072 \\
& \mathrm{~S} \Delta 0 \mathrm{~W} 1 \mathrm{~T} 1=1 / 2 \text {. } 0.03270 .1535=0.0025
\end{aligned}
$$

$\mathrm{S} \Delta 0 \mathrm{~S} 1 \mathrm{O} 1>\mathrm{S} \Delta 0 \mathrm{~S} 1 \mathrm{~T} 1>\mathrm{S} \Delta 0 \mathrm{~W} 1 \mathrm{O} 1>\mathrm{S} \Delta 0 \mathrm{~W} 1 \mathrm{O} 1$, showing that in the SWOT analysis, the priority order shall be: SO strategy, ST strategy, WO strategy, WT strategy.

Through the SWOT analysis, we can get the weight value between factors through the formula, according to the strategic quadrilateral, after the follow-up analysis of the strength, we can get the final selection of strategies. The selection of a strategic quadrilateral can be made under a given rule, and the details are given as follows

(1) Determine of core of the quadrilateral and the quadrant where the core is set determines the formation of strategy. Through the core coordinate formula, $P(X, Y)=\left(\sum_{x i} / 4, \sum_{y j} / 4\right)$, get the core coordinate $P(X, Y)=(0.0715,0.0098)$

(2) Determine the angle of strategic azimuth $\theta$ : According to the core coordinate, asume $\tan \theta=Y / X$ and get $\theta=0.1358$, which is an index to determine the strategy type.

(3) Determine the coefficient ${ }^{\rho}$ for analysis of strategy strength: the determination of strategic quadrilateral is for the follow-up analysis of strategy strength, and the strength coefficient is a strength index. In order to get the strategy strength, we need to get the ${ }^{U}$ strategy positive strength and $\mathrm{v}$ strategy negative strength, positive and negative strengths are got according to the product of positive and negative factors in the four factors of the SWOT, where, $U=S \times O, V=W \times T$ 
Through the formula: $\rho=U /(U+V)$, get $\rho=0.86$

(4) Determine the strategy type: After calculating relevant values, as shown in Fig 5, we get the strategy vector $(\rho, \theta)$ with ${ }^{\rho}$ as module, $\theta$ as azimuth. And the position the vector indicates determines that the current technical innovation strategy should select the strength-based development strategy.

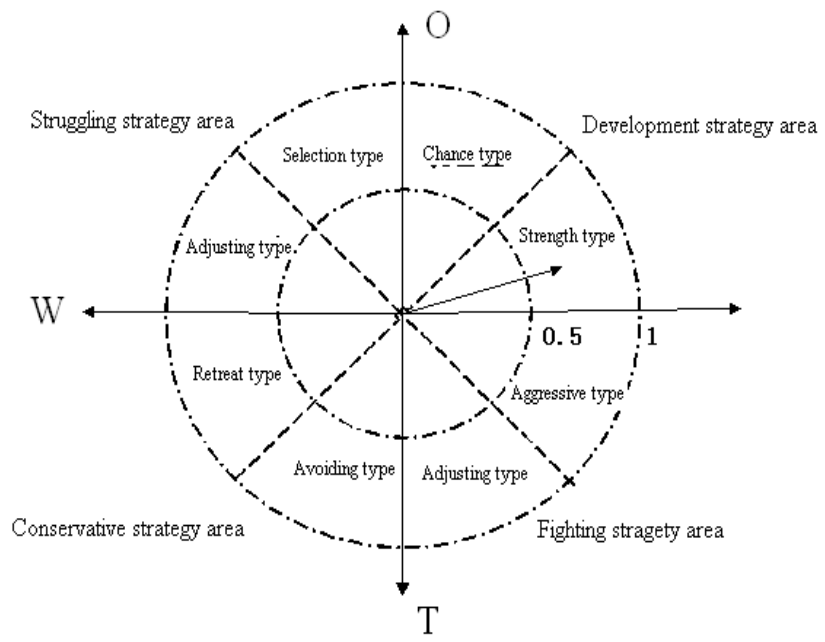

Fig. 5. Strategy Type and Strength Analysis

Based on the strength analysis, it can be seen that the SO strategy shall be regarded by the Yunnan stationed mining enterprise for technical innovation, it needs to make full use of internal strength of its own especially the structural strength, in the meanwhile, it shall actively catch external opportunities such as the 13th Five-Year Plan, etc. carry out independent research and development and innovation, and achieve the transformation and upgrading of the enterprise going with the time, and accelerate the development steadily, calling for a green and innovative development. Implement the strategic distribution of "rooting in Yunnan, home-based, spreading to the surrounding and developing abroad", make full of unique advantages in resources, energy, climate and location, accelerate the development of three major industries as aluminum, lead-zinc and manganese, vigorously develop two new strategic industries as titanium and silicon, and actively advance technical services, financial services, equipment manufacturing, trade logistics, real estate and the like.

Although the conclusion of strategic analysis tend to focus on the SO strategy, yet we should also consider the characteristics of the enterprises and external environment, specifically, after weighing the strength of its own, the enterprise should exert the strength and consider the favorable opportunities brought by external environment, and make good use of the two to deal with various problems, such as trying to avoid threats, and make up the deficiency [14]. Thus it needs to deal with all work concerned, specifically, improving from the following points. First of all, value the production and operation for production and efficiency; strengthen the project construction, enhance the development potential; take advantages of resources to improve the protection. Basic tasks of an enterprise are to ensure the stable output value, and improve the efficiency through technical innovation. The stability basic output value requires the project construction and resources arrangement for development. Second, value technical innovation, improve the development quality; deepen the reform, enhance the vitality of development. Innovation is the soul of for an enterprise's progress, and reform is the drive for development. The organic combination of the two can bring unceasing power for the follow-up development of the enterprise [15]. Reform guarantees the mechanism for innovation, and the innovation generates inexhaustible drive for reform. Finally, strengthen the team construction of the group to provide a strong guarantee for the reform and development, and it needs to build a sound organizational structure and human resources in order to ensure its development. In the meanwhile, the group should strengthen the construction of the Party teams, carefully implement the work arrangements of the group's Party Committee, continue to build the core competitiveness and create a good enterprise culture. Build the Group into a model in the field and make more contributions to the non-ferrous metals industry in China especially the industrial transformation and upgrade in Yunnan Province.

\section{CONCLUSION}

Technological innovation is an important way for metallurgical enterprises to enhance the core competitiveness and also the key for the healthy, rapid and sustainable development of the metallurgical industry. In this article, SWOT analysis is carried out on the technical innovation of a Yunnan-stationed mining enterprise, and deeply analyzes the strength, weakness, opportunities and threat of the enterprise. Based on the SWOT analysis, we have obtained specific and reliable quantitative and qualitative analysis. In order to obtain better development on the basis of the existing good development trend, the Yunnan-stationed enterprise should foster strengths and circumvent weakness, develop reasonable strategies of technical innovation, carry out technical innovation actively, protect the interests and success of R\&D of the enterprise so as to achieve the goal of technical innovation.

\section{REFERENCES}

[1] WANG Y, QI Y. Comparative Analysis on Supporting Technological Innovation of Enterprise and Knowledge Employee[J].2013, 7: 004.

[2] Utterback J.M. Mastering the dynamics of innovation[M].Boston MA:Harvard Business School Press, 1994.

[3] Fu Jiaji, Technical Innovation [M] Beijing: Tsinghua University Press, 1998

[4] Ma Minxiang, Peng Jingli, Introduction to Technical Innovation [J]. Yunnan S\&T Management, 2000,01:27-29

[5] Zhao Jun, Discussion on Construction of Informatization in Stateowned Metallurgical Enterprises [J]. Discovering Value, 2014 (16): 57 57.

[6] Wei Xiaolun, Research on Strategic Management Mode of Core Competitiveness-based State-owned Metallurgical Enterprise Groups [D]. Tianjin University, 2011

[7] Analysis[J]. Value Engineering, 2014, 20: 102. 
[8] Yin Xiangqing, Han Tianshuai, SWOT Analysis on Technical Innovation and Strategic Mode Selection of Medium and Small-sized Enterprises [J]. Value Engineering, 2009, 28(3),

[9] Jiang X, Wang Q, Zuo W. Study on Construction Science \& Technology Development using AHP-SWOT Method[J]. 2015.

[10] Wang Bo, Wu Nan, Research on Development Strategy of SWOT-AHP Model-based Financial Information Service-taking Shanghai as an example [J]. S\&T Management Research, 2015, 35(4): 174-180.

[11] Song Jianxiao, He Yaping, Huang Senwei, Analysis on Development Strategy of Farmer Startup Park in Fujian and Taiwan on the Basis of SWOT-TEST Model [J]. Fujian Forum: Humanities \& Social Sciences, 2015 (4): 148-153.

[12] Zhou Min, Troubles and Way Out of Medium and Small Foreign Funded Enterprises in China [D]. Shanghai International Studies University, 2014

[13] Jifa W, Haiyan A, Hang C. The Research of Chain Structure and Value Realization Mechanism Based on Innovation Chain in S\&T Service Industry[J]. Science \& Technology Progress and Policy, 2015, 15: 012.

[14] Wang Qian, Han Xingyong, Research on Development of Maritime Cultural Industry on the Basis of AHP-SWOT, taking Ningbo region as an example [J]. Ocean Development and Management, 2016, 33(1): 103-108.

[15] Zhao Changwu, Scientific Use of Five Frequent Tools for Strategic Analysis [J]. Journal of Wuhan Metallurgical Manager's Institute, 2005, 15(1): 45-49. 